\title{
A Brief Survey of Science and Scientists at McGill
}

\author{
by M.A. Whitehead
}

The following paper is a revised version of the Presidential address presented at the meeting of the James McGill Society held at McGill University, 29 February, 1994.

L'article suivant est une version révisée du discours présidentiel prononcé à l'occasion de l'assemblée de la James McGill Society qui a eu lieu à l'Université McGill le 29 février 1994.

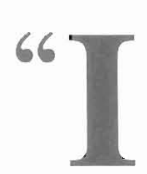
n Nomine Patris et Filii et Spiritus Sancti." A scientist would have used this phrase to open his address in earlier times, admitting that only by the guidance of the Holy Ghost could he understand the creations of God (although he need not have intoned it in Gregorian Chant).

Science is the quest to find immutable and universal laws that govern processes, presuming cause and effect relation. It does, in a sense, leave out humanism; yet at its basic level all the products of science form, influence, and cause the humanistic view of the world.

In 1838 McGill College planned its Chemical Apparatus room; it could have been one small step for science but unfortunately the room was never built. The first science subject taught at McGill was meteorology, introduced in 1833 and entrenched when Smallwood built his observatory in 1846. In 1843 there was an expectation that the Arts Faculty would replace the Medical Faculty in teaching chemistry to medical students, but this did not occur. Nevertheless, Chemistry earned a high profile when in 1846 Thomas Christie won the Chemistry Prize in Medicine.

The development of scientific ideas at McGill reflected the interests of researchers who had been educated in the British Isles where, during the preceding century, the enterprise of science had grown and changed. Natural History had replaced Natural Philosophy and special institutions developed with narrow, specialized interests. Expeditions brought back to England specimens from Australia, India, China and the Americas. There was great curiosity to see if the samples could be grown in places other than their origin: spices, rices, breadfruits, teas and cottons. In cities, discussion groups evolved to debate scientific matters, steam engines, pottery, electricity and chemistry. Business men met with professional men to discuss intellectual matters, finance research and develop Civic Pride. Gradually Chemistry came into its own, no longer the purview of the apothecary and the physician. The Universities of Edinburgh and Glasgow, were at the forefront for the teaching of Chemistry and Science. In Montreal the members of the Natural History Society, founded in 1827, eventually taught science at McGill College.

The Visitation to the Royal Institution during Principal Meredith's tenure, in 1847, specifically recommended the establishment of Chairs in Chemistry, especially of a practical nature using the style of teaching then in use at the Skakel School in the Place d'Armes.

William Sutherland, appointed Lecturer in Chemistry in 1849, and Professor in 1853, replaced Hall in medicine. He was paid $£ 3.15 .0$ per course. He lectured on organic and inorganic chemistry to all firstyear medical and third-year Arts students, except those selecting botany! The lectures were given in the Mechanics Institute on St. James Street. In 1835 he gave a course on "Chemistry of Life." A similar course, given by David Harpp, Joe Schwarz and Ariel Fenster is still offered in the Chemistry Department. It is designed to attract public interest, for everything we are, think and do is chemical. Sutherland gave the University his Philosophical Apparatus, a collection of instruments for performing or demonstrating the principles of physics and chemistry. It was the most modern in the Dominion.

The appointment of William Dawson (Fig. 1) in 1855 as Principal of McGill revitalized the University. 
A Brief Surey of Science and Scientists at Mcom

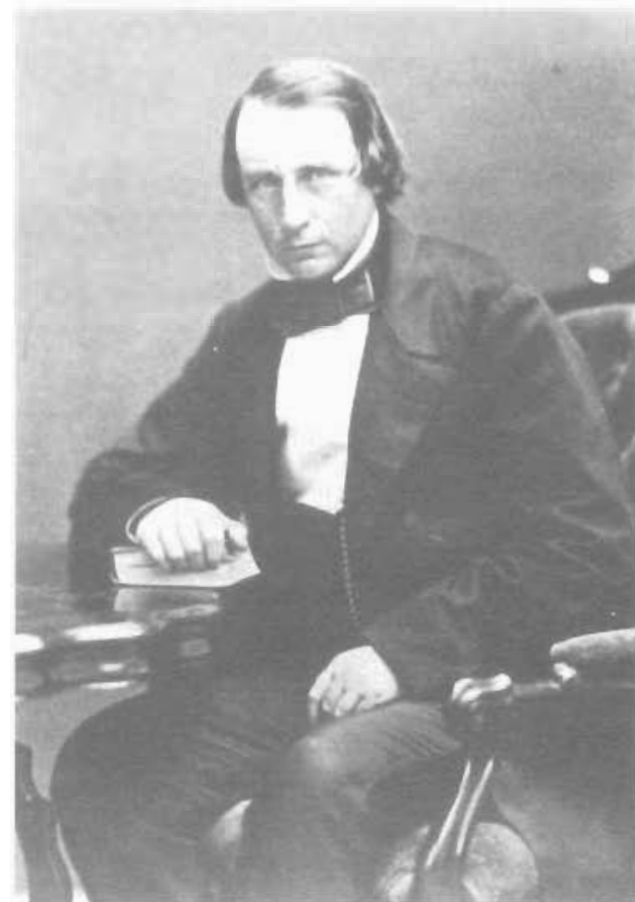

Figure 1. John William Dawson, 1859. (McCord Museum of Canadian History. Notman Archives)

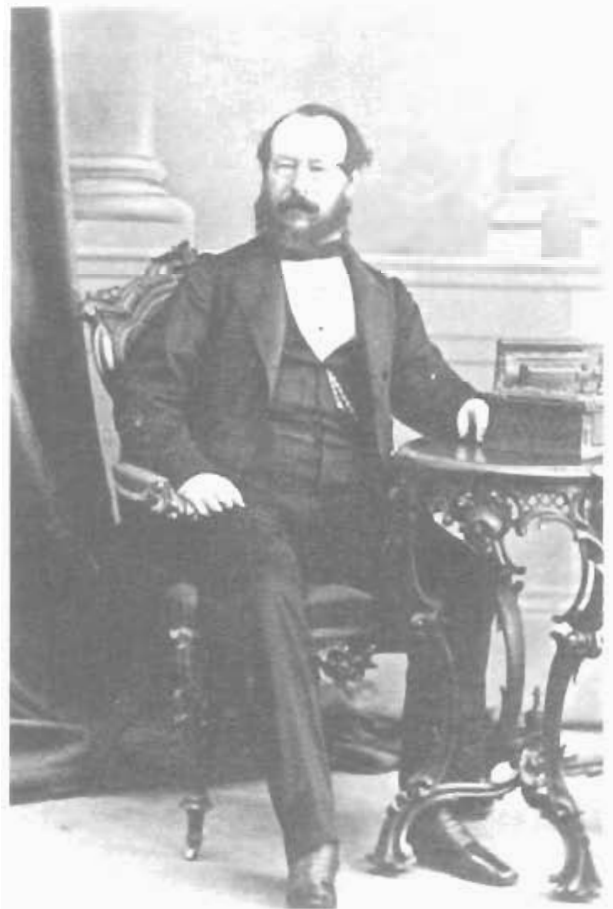

Figure 3. Thomas Workman, 1864. (McCord Museum of Canadian History. Notman Archives)

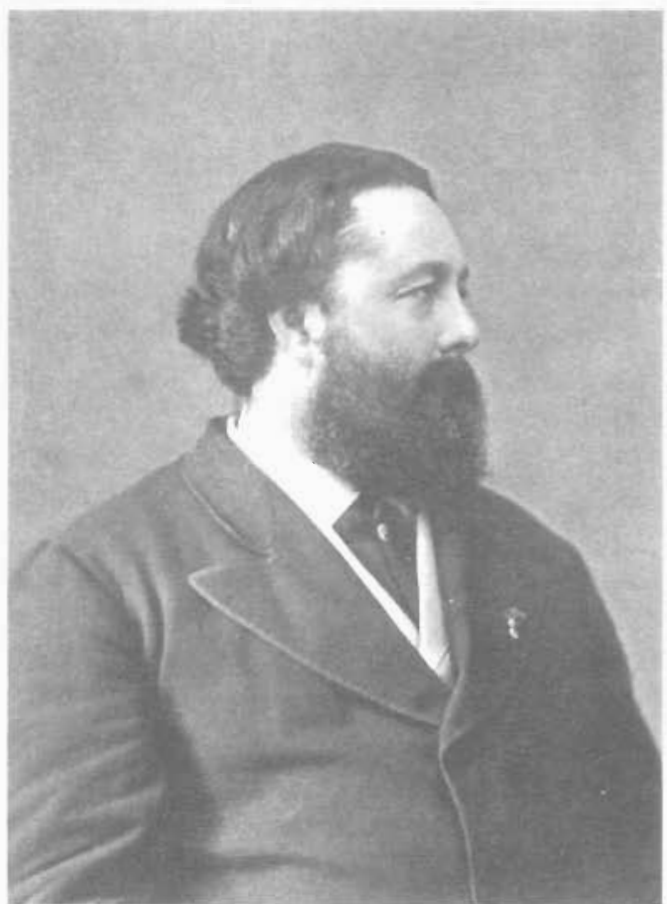

Figure 2. T. Sterry Hunt (Leo Yaffe, History of McGill Department of Chemistry, p. 5)

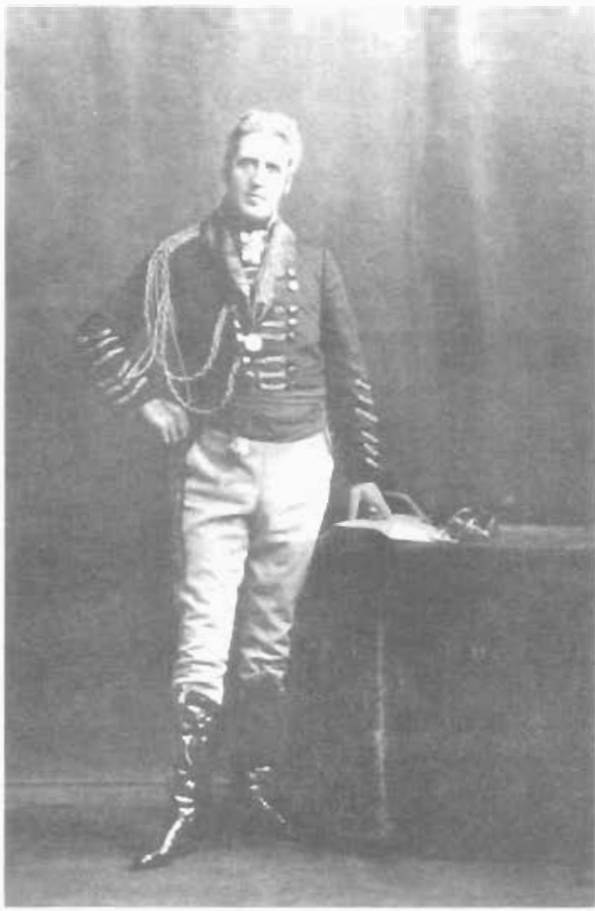

Figure 4. R.F. Ruttan

(Leo Yaffe, History of McGill Deparment of Chemistry, p. 9) 


\section{A Brief Survey of Science and Scientists at McGill}

He soon liberalized the Arts courses by introducing more courses in science, naturai philosophy, chemistry of life, zoology, heliography and engineering, following the American and not the British tradition. The supporters of McGill University favoured a broad Protestant tradition rather than an Oxbridge tradition. It would be professional and practical, with research independent of its intrinsic charm and value: it would be mechanical, manufacturable, useful to agriculture and to the material welfare of the Nation. A.N. Whitehead had observed that the greatest invention of the nineteenth century was the idea of invention itself; how to invent, not why!

Sutherland did do research. He studied the metallurgical structure of railway lines, built an Observatory where, in 1883, Clement McLeod cooperating with Greenwich, observed the transit of Venus. This allowed him to measure the exact longitude of the observatory. Scientists are always too intelligent to do what Society wants; it is the future which is of interest, not the present. Technology may satisfy the present greed of society and aid in the control of society by those in power, but science will always break free giving each individual the freedom to dream and the responsibility to act on that dream.

When William Moison paid for a new building in 1862 it was to contain "suites" of apartments for a museum, chemical classroom and laboratory. T. Sterry Hunt (Fig. 2) joined the faculty and, like all new members, was loaded with courses to teach! Nevertheless, Hunt did make time for research and, at the request of Thomas Workman (Fig. 3), who was President of the City Bank Montréal, and whose home would later be demolished to make way for the construction of the Otto Maass Chemistry Building, Hunt developed $\mathrm{Cr}_{2} \mathrm{O}_{3}$, the sesquioxide of chromium, in 1857. It was a permanent dye used on all United States banknotes, many Canadian banknotes, as well as bills in England and Russia. Few students signed up for Hunt's courses and he left for the Geological Survey in 1.871. He was given funding of $\$ 800$ for three years beginning in 1864 by Christopher Dunkin, an MPP. Hunt complained that he needed gas in the laboratory to do his research, and was told it was only to be used to heat the laboratory! In 1868 Girdwood and Blackwell were offered $\$ 1200$ per year but were expected to do assays in the laboratory to earn money.
At this time Physics supplanted Natural Philosophy. The development of physics as a discipline resulted. in the building of a dynamo and the introduction of electric lighting in the new physics building. Electricity emerged as a fulll-fledged study in 1888. John Cox. furthered this research in the new Macdonald Physics Building, focussing on $x$-ray research.

B.I. Harrington and G.P. Girdwood built their own laboratories and rented them to McGill University, which subsequentily purchased the lab tables. for $\$ 100$ in 1882. Harrington joined Hunt in 1871 to lecture in "Assaying and Mining" and then Chemistry. Geologist G.F. Armstrong was appointed in August 184i to start the Department of Applied. Science. In 1880 Harrington needed. $\$ 1.50$ from the Administration for equipment and, as is the case today, was granted less than needed-\$100! It is interesting how scientists do more with less and administrations less with more. Chemistry was changing and the changes would hit McGill suddenly. McGill survived by moving people around like chess pieces, retaining experienced staff where needed-Girdwood was moved to a Chair of Theoretical Chemistry in Medicine (surely an oxymoron or perhaps just too true?), and Craik retired.

A.L. Lavoisier (guillotined during the Revolution) had developed a new Chemical Language in his Traité Elementaire de Chimie (1789). It reformed the nomenclature, changed Chemistry from a qualitative to a quaniiative subject, and gave a theoretical structure to the subject. Ai McGill, these changes in the subject were reflected in the Honours degree in Chemistry. Theoretical Chemistry had come of age. In 1898 the new Macdonald. Chemistry Building was opened.

F.C. McIntosh laid the foundation for the study of Physical Chemistry at McGill from 1900 till 1915, and paved the way for R.F. Ruttan, a pre-eminent, ambitious man from Berlin (Fig. 4). Ruttar found the research conditions primitive; he passionately favoured grants-in-aid and. scholarships. Ruttan wanted Graduate Students and. Research Students-the young, the enthusiastic, the dedicated-so that they could mature and progress from the B.Sc. through the M.Sc, to the Ph.D. and Post-Doctoral positions. Teaching would complement research to strengthen the Department. 


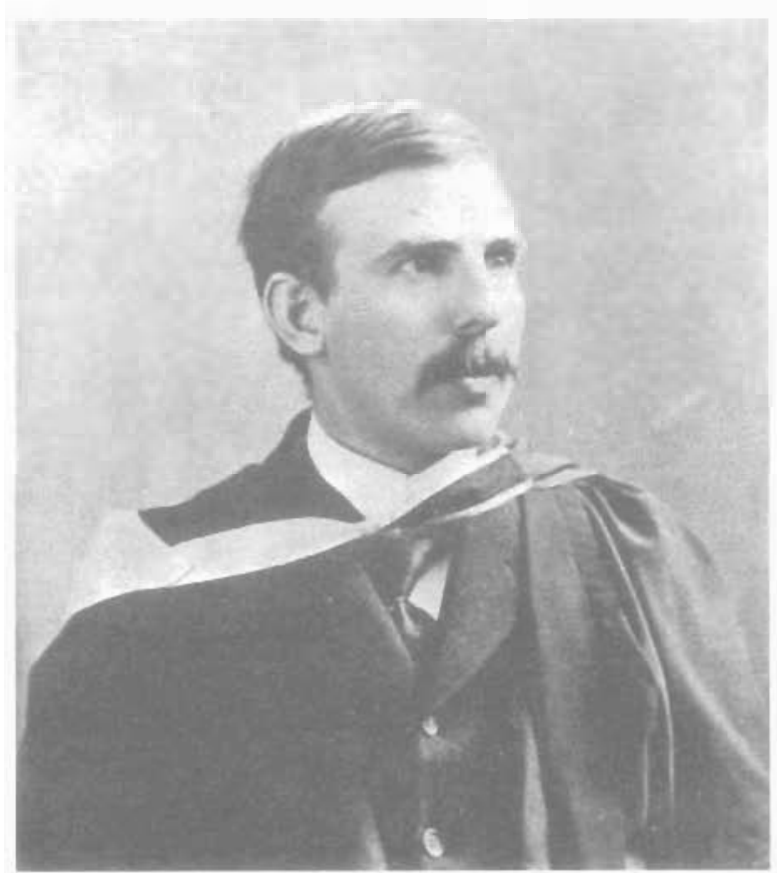

Figure 5. Ernest Rutherford

(Leo Yaffe, History of McGill Department of Chemistry, p. 12)

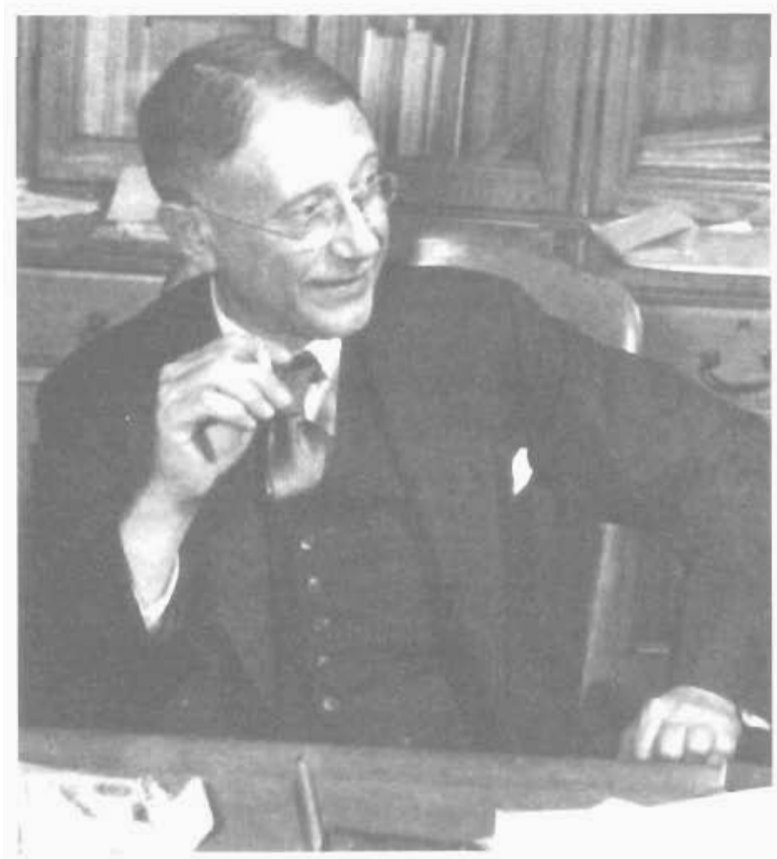

Figure 7. Otto Maass, 1946.

(Reproduced from Deadly Allies, Canada's Secret

War, 1937-1947, by John Bryden, pp. 128-129)

Photo credit: Frank Royal/NFB/

National Archives of Canada

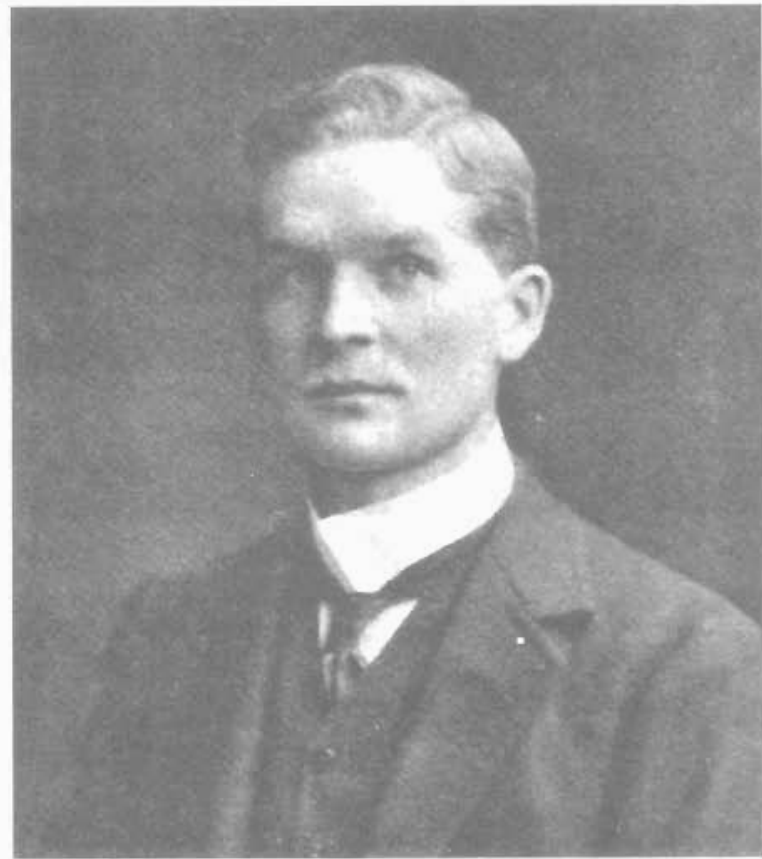

Figure 6. Frederick Soddy.

(Leo Yaffe, History of McGill Department of Chemistry, p. 14)

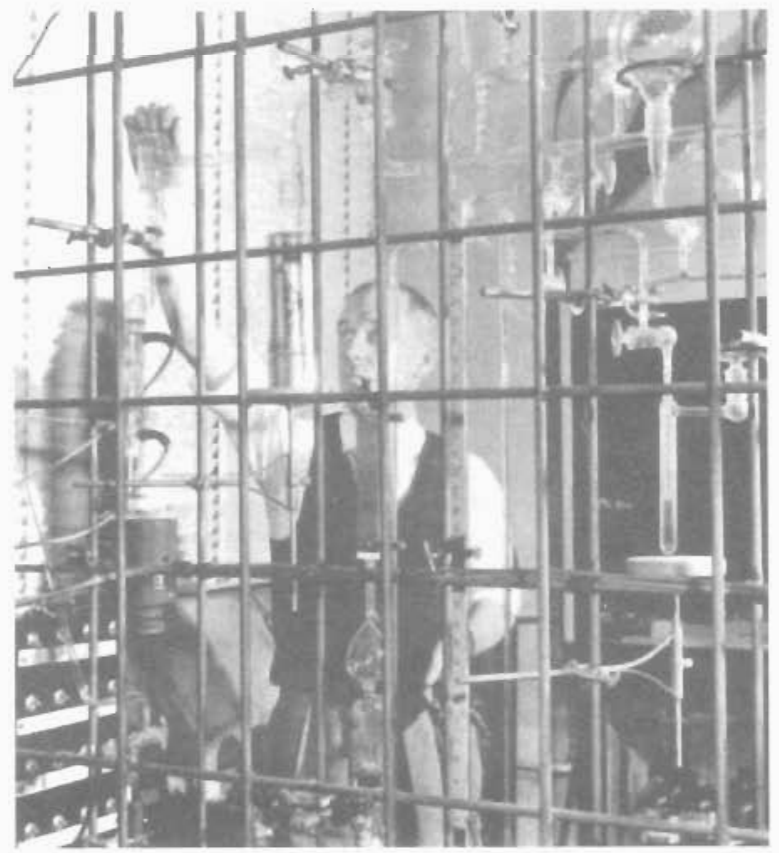

Figure 8. E.W.R. Steacie, 1948.

(Reproduced from E.W.R. Steacie, by M. Christine King, p. [xvi])

Photo credit: Public Archives of Canada.

PA-145317. 
J.W. Walker was recruited from Leipzig in 1921 , and joined with N.N. Evans and T.M. Johnson, who had come from Breslau, where he had studied explosives. John Cox and Hugh Callender produced the first Canadian $\mathrm{x}$-rays in the new Physics Building. Later, in 1894 G.P. Girdwood and N.N. Evans set to work using them in Medicine, applying them to numerous studies at the Montreal General Hospital. The twenty-seven-year-old Ernest Rutherford arrived in 1898 (Fig. 5) to study the physical aspects of radiation as well as subatomic chemistry and transmutation, building on the Curies' isolation of radium in 1898 and their obtaining it as a metal in 1910 by electrolysis. It was ideal to study in a building specially designed for a department dedicated to research in magnetism and electricity. Rutherford caused helium nuclei to shoot out electron streams and penetrating $x$-rays. Their effects and products were analyzed with the help of F. Soddy (Fig. 6) of the Chemistry Department. Rutherford was mentor to several students who later did research all over the world: H.T. Barnes and R.W. Boyl studied mass energy; Soddy studied atomic disintegration and discovered neutrons; and finally, Otto Hahn discovered U235 fission in 1939. In the long term, Rutherford's intellectual and research legacy helped to establish the Canadian Uranium Ore and foster atomic research from the 1940's to the 1990's.

In 1913 a fundamental change in scientific research at McGill and in Canada would be effected by the arrival of Otto Maass (Fig. 7). A Swiss-German born in New York, he had studied in Berlin under Walter Nernst, who at the advent of war advised him to flee to Switzerland. Biting his cheeks to fake tuberculosis and spitting blood to prevent the border guards getting too interested in him, Maass succeeded in escaping. In Berlin he had worked with Arthur Eddington, whose "Experiment with Time" should have allowed Eddington an insight into relativity.

D.J. Harrington and Ernest Rutherford in 1906 were members of the Graduate Studies Committee overseeing seven Ph.D. students. Annie Macleod (Chemistry) received the first Ph.D. awarded at McGill, and the first Ph.D. in Canada, although she did most of her research work at Bryn Mawr. She later became Dean of Women at Barnard.

World War I caused a sudden increase in scientific research: it became necessary to advance the war effort, to develop means of defense and security, and to develop more efficient weapons of destruction. Dr. Louis King studied the propagation of sound waves, the design of foghorns, the detection of ships at sea, as well as oscillators for signalling between the newlydeveloped submarines. Dr. Howard Barnes designed a vortex gun fired from ships to flush submarines out of the sea. Dr. C.J. Lynde developed moveable defence shields for vehicles, which resulted in the design of the earliest successful tanks. Dr. A.S. Eve and Dr. R.W. Boyle developed ASDICS (anti-submarine detection) and LeaderGear, a device to guide ships in and out of harbours. LeaderGear could also be used for sound ranging in battlefields. Chemists R.F. Ruttan, F.M. Johnson, V.J. Harding and F.W. Skirrow manufactured acetone from acetylene, studied explosives, and attempted to develop a defence against poison gas, especially phosgene, which the Allies feared the Germans would use. In metallurgy, Dr. A. Stanfield developed the production of metallic zinc, the refining of copper, the production of magnesium and the purification of nickel ores-all needed to produce shells, bullets and equipment including hardened steel. The Shawinigan Company was created to produce the patented products resulting from this research, which included acetone among other solvents and reactants. A. new chemical industry was emerging in Canada.

Otto Maass studied physical laws, and chemicai and critical phenomena, and changes of state; he had a status in North America that equalled that of Wilhelm Ostwald, the father of Physical Chemistry, in Europe. In 1926 the eccentric E.W.R. Steacie (Fig. 8) graduated (Ph.D.) wearing a dentist's hood because they had run out of Ph.D. hoods. Steacie stayed on at McGill to do research and teach on a Sterry Hunt Fellowship, financed by money left by Hunt at his death in 1892 .

Steacie won a Royal Society of Canada award, and elected himself Director of Research. Since he was already a Fellow of the Royal Society he also awarded research money to himself, wrote reports to himself, answered and criticized the reports himself, wrote and thanked. himself for the reports, and presented all this correspondence as evidence of the correct use of the funds! Today, accountants and administrators would discredit him on such practices and destroy a great scientific mind. What did Steacie do with the money he 


\section{A Brief Survey of Science and Scientists at McGill}

gave himself? Scientists try to use research money carefully and frugally; it is the research and science which count: do and get as much per dollar as is possible, is the scientists creed. Steacie produced single crystals of silver, studied the viscosity of liquid halogens, the solubility of oxygen gas in silver, the solubility of hydrogen gas in silver, the osmotic pressure of very dilute solutions, the kinetics of methyl formate decomposition, the design of a gas combustion pipette, the energy change in unimolecular reactions, and the catalytic activities of liquids and solid surfaces.

The Physical Society and Chemical Societies (1902) had educated, enlivened and brought together undergraduates, graduates and Professors in the exuberance of their research. In 1921 a group of the most influential, scientifically alert and prominent scientists founded the McGill chapter of the Society of The Sigma Xi. The scientists were concerned that science was fragmenting into narrow disciplines where researchers were unaware of each other's work. They foresaw the problems, needs and solutions years before bureaucrats and politicians. These scientists agreed with A.N. Whitehead who had been invited to address them: that information is dangerous when it has no place to go, when there is no idea to which it applies, no pattern that it conforms to and no purpose that it serves. Information without regulation can be lethal. But only those who understand the source of the information can evaluate and regulate it.

Consequently the Sigma Xi Honour Society was founded, Undergraduates, postgraduates, research scientists and professors were elected to the Society based on their research achievements. The meetings were traditional: a cheese and wine reception, a lecture, discussion and dinner. In 1936 it was reported that the Society was very important to the scientific life of McGill. Yet in 1996 it is struggling for existence, despite the importance most scientists give to interdisciplinary research.

In 1922 McGill set up the Faculty of Graduate Studies and Research, the culmination of a study done in 1902 which suggested that a decrease in the Englishspeaking population of Montreal would require the University to cull a larger area for graduate students, including the United States and the United Kingdom. While $90 \%$ of the graduate students came from outside
Quebec, there were two National Research Council Scholars from Quebec. Former graduates were very good at sending their students to McGill to earn their research degrees.

In 1927 the Pulp and Paper Institute was created. Lack of Government interest in both industry and research had forced the paper companies to join together to finance an organization to do research into one of Canada's natural and national treasures. Harold Hibbert joined the Institute in 1925 to investigate the aromatic bases of lignin. He developed the process of alkaline oxidation of wood pulp and he extracted the flavour vanillin from wood pulp using ethylene glycol. Hibbert retained ownership of all the patents. This artificial production of vanillin almost destroyed the market for natural vanillin produced from the vanilla bean in South America.

J.S. Foster came to the Physics Department from Niels Bohr's Laboratory in Copenhagen and taughi quantum physics. His contemporary W.H. Watson developed aspects of quantum theory, and made the dream of a cyclotron at McGill a reality. Watson also designed and studied radar antennae. G.S. Whitby developed a process for the vulcanization of rubber and did research in organic reaction accelerators before leaving McGill to head the National Research Council.

One of the most important breakthroughs in modern polymer chemistry occurred in the Chemistry Department when Plexiglass was created by the research student Bill Chalmers (Ph.D. 1930) through the polymerization of methyl methylacrylate and its substituted derivatives, as well as its chlorinated and brominated substituted compounds. It lead to the foundation of Rohm and Haas Inc.

Steacie went to the National Research Council in 1939. Formerly apolitical, his stint of research between 1934 and 1936, first with K.F. Bonhoeffer in Germany and later with Arthur Allmond in England, caused Steacie to turn pro-Hitler. This created not a ripple of comment, neither from McGill nor from Otto Maass, who was staunchly anti-Hitler.

Steacie studied atoms, molecules, and free radicals, searching for a way to test Moses Gomberg's theory of the existence of stable free radicals. Steacie 


\section{A Brief Survey of Science and Scientists at McGill}

developed a beautiful reaction

$$
\text { RONO ----> } \mathrm{RO}+\mathrm{NO}
$$

and studied its rate increase with changing $\mathrm{R}$, where $\mathrm{R}$ is organic, $\mathrm{CH}_{3}$ - methyl, $\mathrm{C}_{2} \mathrm{H}_{5}$ - ethyl etc.

At the National Research Council Steacie fought for research monies and grants for research students, professors and faculty.

Otto Maass built his own equipment to study critical state phenomena, the equations of state, sound propagation, specific heats, sulphite treatment of wood chips and the first production of truly pure hydrogen peroxide, which proved to be explosive, and to be a perfect rocket fuel.

Haber in 1919 got the Nobel Prize for the syntheses of ammonia, which lead to diphosgene, chloropicrin, and dichloro-diethyl sulphide-mustard gas, which blisters skin, blinds, rots lungs and is lethal. Luckily it was impure; when made pure in Canada it was dreadful, as the tests on Canadian soldiers showed. It is also one of the most widely used anti-cancer drugs.

The High Command, in 1940, was interested in casualty efficiency: bombs or chemicals. What was the ratio of casualties for high explosives to that of gas and what was the relative cost? Maass supported Sir Frederick Banting (Nobel Prize 1923 for insulin) who was overly modest but favoured chemical warfare righi up to the time of his death in a plane crash in February 1941. He worked on warime međicine at Porton Down. in 1916 and knew that the Germans had the lead in chemical warfare. The government was not interested in research for the war ahead but three private individuals agreed with Banting, that it was "a war of scientist against scientist".

John David Gaton, Sir Edward Beatty of the CPR and Sam Bronfman of Seagrams organised a fund. raising campaign to help finance scientific research, each pledging $\$ 250,000$ to the War Research Project. The fund reached $\$ 1,300,000$. The government paid back the money when the research proved successfuil Maass and Banting dedicated their efforts to Canada and were supported by General A.G.L. McNaughton, a graduate of McGill Physics and Engineering, who headed the National Research Council. He set aside, at Suffield, Alberta, a $50 \times 50$ mile test area for explosives and chemical testing.

At. McGill, Bob McIntosh took over running Otto Maass' research after Maass was appointed Director of Chemical Warfare, in charge of chemical and biological warfare research for Canada. McIntosh with two young graduates, Richard Mungen and Templeton Hugell, tried to reproduce the chemical warfare research they thought Otto Ruff. was doing in Germany-replacing phosgene as a chemical warfare gas. They burned sulphur. in fluorine gas to give an expected non-toxic product, but the gas promptly killed a rat; compound $\mathrm{Z}$ $\left(\mathrm{S}_{2} \mathrm{~F}_{6}\right)$ had been discovered. This gas was four times more toxic and lethal than phosgene and the only new lethal gas discovered in WWII. It was odourless and emitted no early-warning smell. It was a well-kept secret until 1989, and is still talked of discreetly. It put Canadian science research on the world map. At McGill labs, no one except authorized personnel were admitted, not even the custodians who regularly cleaned the laboratories.

At McGill compound $\mathrm{Z}$ was so secret that the formula was never reproduced in any document. There was no admitiance to laboratory 401 , where the sun, filtered by dirt through opaque windows, glinted on mercury in floor cracks so large that any determined spy could crawl through them! When Otiawa finally demanded to see the result of the research, government officials requested 100 grams of the gas to test the efficiency of their gas masks. The gas was transported to Ottawa by train by Fred Lossing. He carried it in a sealed. glass container which, was further sealed in a Dewar containing dry ice. The train was filled with business men sitting all around, blissfully reading newspapers, yet there was enough gas on board to kill everybody on the train and for several thousand feet around it.

Lossing awoke in the Hotel that night, sweating and unable to breathe. There was a dreadful smell-- $Z$ was loosel He rushed to the window, threw it up, and. gasping looked out: they were tarring the road! In 1940 when Fred Lossing joined. McGill from Western University, which had good laboratories, he found the scientists fabulous and the laboratories utterly awful. There was no alternating current, no hot and cold water, no steam, no compressed air, and the fume hoods had no suction! 
On one occasion Alison Flood, who worked for Maass, hearly got sacked for stopping an experiment. Maass, in trying to prove he could resist a gas attack with sheer German resolve and the strength of mind over matter, began turning purple.

At Macdonald College Dr. W.D. MacFarlane directed research in food production, storage, antirancid agents, and the toxicity of the new insecticide DDT; Dr. J.G. Armstrong and Alair Lips studied the nutritional value of food in the Arctic, and assaying the value of vitamin $C$ in food. The Pulp and Paper institute conducted research into durable paper for shoe insoles and soles, chewable paper for documents so spies could swallow them, impervious paper for prisoner-of-war letters, water-resilient paper for sandbags and electrical conducting.

Dr. R.L. Noble used a sea-sickness swing to test the Army's $\forall-12$ ethyl B-methyl allyl thiobarbituric acid and the Navy's Pink Pill anti-sea sickness remedies, as well as various other concoctions of belladona and barbituates.

Physicists under the direction of Dr. H. Watson, F.R. Terroux and Dr. J.S. Foster developed an antenna for finding aircraft height. The most important achievement was the development of slotted waveguides, and the development of an accurate theory of radar.

The Physics Department also took over the unopened. Université de Montréal laboratories. Thirty percent of the McGill Physics faculty moved to the alternate laboratories. There, J.P. Cockcroft, under Steacie's direction, not only developed a successful energy pile reactor, assembled at Chalk River, but also designed a heavy water reactor and did research into the atomic bomb.

Explosives research greatly interested the chemists, and James Ross and his student Robert Schlessler developed an efficient way to make the super explosive RDX which replaced TNT in the Aliles repertory of bombs. On one occasion they had to take a $20 \mathrm{lb}$ sample for testing to Woolwich outside London, England. RDX is stable if not dry: it is initiated with mercury fulminate. They had to keep a sample of RDX under water and in sawdust on the roof of the Biology

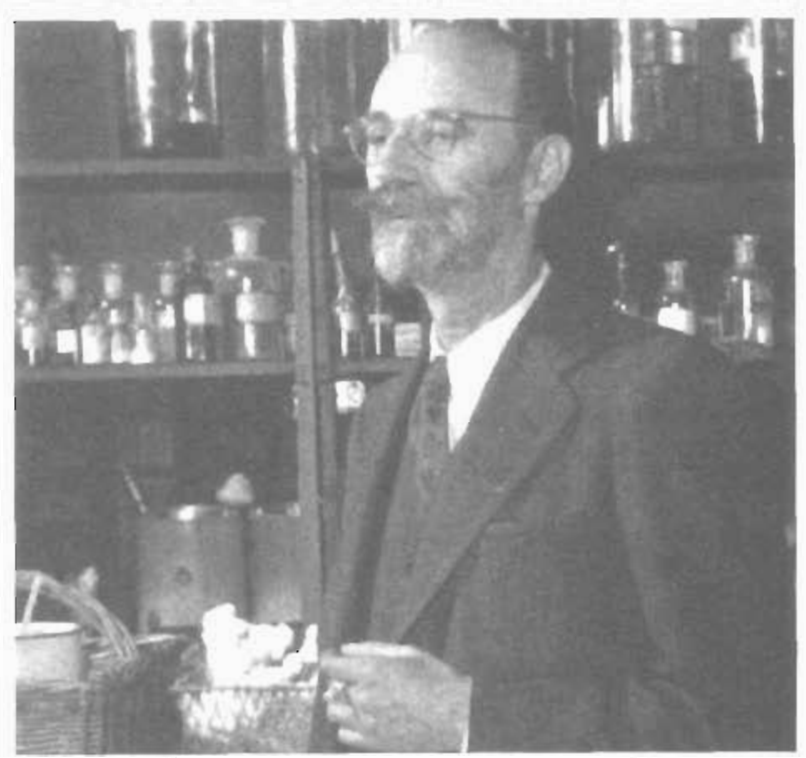

Figure 9. E.G. D. Murray, 1946. (Reproduced from Deadly Allies: Canada's Secret War, 1937-1947, by John Bryden, pp. 128-129)

Photo credit: Frank Royal/NFB/ National Archives of Canada)

building for two days because the plane taking them to England was delayed. They then flew in an unheated fuselage for low altitude flying, holding the sample in their laps! However, they insisted on being inside the relaively warm section of the plane for high altitude flying, arguing that the container might shatter if the water froze! At Woolwich Arsenal the RDX test passed the British specifications.

Another type of bomb was to carry biological agents. Research was conducted under the direction of E.D.G. Murray, a bacteriologist at McGill (Fig. 9). He believed that the enemy could be defeated with poisoned paper, mosquitoes, rats and other carriers spreading anthrax, plague, murin typhus or botulinus toxin. All were being developed at Grosse Ile, a small island downstream from Quebec City. At one time during the War there were rows of trays of anthrax laid out to fill bombs. The security fence around the facility was full of holes and the doors to the laboratories unlocked! Maass rapidly reorganized safety and security practices.

R.V.V. Nicholls, a McGill chemist, developed plastic explosives and the efficient production of toluene from the cyclodehydrogenation of petroleum fractions. 


\section{A Brief Survey of Science and Scientists at McGill}

He studied the nitration of p-cymene, the use of betonites as polymeric catalysts, and improved the synthesis of 1.1-diphenyl. ethanes making the process resulting in synthetic rubber and DDT cheaper and more efficient.

When peace broke out all the research monies and all the extra-ordinary employment ceased. McGill, generously and with great foresight, gave $\$ 5,000$ to returning Faculty to siart up individual rescarch. In geography George Kimble and Kenneth Hare began research in meteorology, climate and biogeography in the Canadian North, building on the work of James Gill who in 1920 discovered Iron Ore on the QuebecLabrador border. In the 1950 's the mining of this iron ore deposit required the building of a railway to the Canadian North, which opened up the area to research in glaciology and geomorphology and led to cooperative research with the Arctic Institute whose library was at McGill. In warmer climes, the Bellaire Instifute in Barbados was created to conduct research into coral reefs, irrigation and land reclamation.

Physicists in the Foster Radiation Laboratory used the cyclotron (now in a modern form used in the Montreal Neurological Institute) to create a proton beam to study radioactive emissions from atomic bombardments, the reactions of nuclei, and delayed proton events. From an extracted proton beam, they studied nuclear reactions, and proton-proton collisions. In the Eaton Laboratory the physicists studied microwave optics, microwave spectroscopy, and atomic clocks, which later lead to masers and magnetic insulators.

The chemist Leo Yaffe used the cyclotron to study $\beta$-radiation, neutron-induced reactions, nuclear fission and isomer ratios, and applied it to analyzing archeological artefacts from the ancient trade routes in Turkey, Greece and the Ottawa valley.

At McGill the first "gene machine" was deveioped by Kevin Ogilvie. It formed the basis of a burgeoning industry as well as fundamental medical and biochemical rescaich. Stanley Mason investigated blood and wood pulp flow and Bernard Beileau developed a morphine analogue which was non-narcotic, nonaddictive and with no side effects called buturphanol. He also developed 3TC used to fight AIDS. This work led to the founding of Bio Chem Pharma Inc.
I have presented a bird's eye view of one hundred and fifty years of research at McGill and I have touched on only about $5 \%$ of it!

The future of Science in Society and at McGill may look bleak. The scientists are overworked, underpaid, and scrambling for money. The province may seem alien to their interests, and the country disinterested in science. However this survey proves that scientists will always continue to do science because they believe that only science will lead to an understanding of the natural world, the betterment of mankind, and a glimpse into the mind of God.

\section{Bibliography}

Bryden, Lohn. Deadly Allies: Canada's Secret War, 1937-1947. Torontu: Mcclelland \& Stewart, 1989

Fetherstonaugh, R.C. McGill Universiry ai Wor, 1914-1918, 19391945. Montreal: Micrill University, 1947.

Fresco, J. Maass Spectrum. Montreal: McGill University, Depanmeni of Chemistry, Septenber, 1992.

Frost, Stanley Brice. Whe Gill Universiny for the Advancemen of Learning. v.1 1801-1895; v.2 1895-1971. Montreal: MeGill-Queen's University Press, 1980

King, M. Christine. E.W.R. Steacie and Science in Canada. Toronto: University of Toronto Press, 1980.

McBryde, W.A.E. et al. Essuys in Chemical Ristory. Ottawa: Canadian Society of Chemistry, 1988.

Polkinghome, J. One World: the Interactions of Science und Society. London: SPCK, 1986.

Polkinghorne, J. Science and Creation: the Search for Understanding. London: SPCK, 1986.

Postman, Neil Technology. New Yok: Vintage Pres:, 1993.

Saul, John Ralsion. Voltaire's Bastards. Toronio: Pengum Books, 1992.

Warringion, C.J S and R.V. V. Nicholls. A History of Chemistry in Canada. Toronto: Pitman and Sons, $194 \%$.

Whitehead, A.N Science and the Hodem World. Cambriage, Eng.: Cambridge University Press, 1953.

Yate, Leo, Aistory of McGill Depantment of Chemisry. Taik given to the James McGill Khistorical Society, 13 April, 1978. 52 pp. 